\title{
Foreign capital impact on insurance market development in EU-15 countries
}

\author{
Sławomir I. Bukowski, Marzanna Lament
}

A B S T R A C T

Objective: The objective of the article is to investigate how foreign capital influenced the development of insurance markets in EU-15 countries.

Research Design \& Methods: A critical review of literature is undertaken, contents of factors which influence development of insurance markets are analysed, and econometric methods are applied. A panel model is constructed and results of its estimation are analysed.

Findings: Insurance markets in particular countries develop under the influence of many factors. The share of foreign insurance companies is treated as a structural factor. There is previous research into this subject was conducted, whose results do not confirm a clear impact of foreign capital on the insurance market's development. The study indicates that the development of insurance markets - measured with the penetration rate and with the ratio of insurance density - is affected by shares of foreign capital in life insurance companies.

Implications \& Recommendations: To verify the hypothesis concerning the impact of foreign capital on the development of insurance markets, scholarship requires further studies of another group of countries (insurance markets).

Contribution \& Value Added: This study will contribute to the development of theories concerning factors of the development of insurance markets.

\begin{tabular}{ll}
\hline Article type: & research article \\
Keywords: & international finance; insurance market; insurance companies; for- \\
& eign capital; panel data model; random estimation
\end{tabular}

JEL codes:

F3, F4, G2, 004

\section{Suggested citation:}

Bukowski, S.I., \& Lament, M. (2020). Foreign capital impact on insurance market development in EU-15 countries. Entrepreneurial Business and Economics Review, 8(3), 205-219. https://doi.org/10.15678/EBER.2020.080312 


\section{INTRODUCTION}

The development of insurance markets and its determinants must be considered important for a number of reasons. First, insurance companies and banks are major financial market players in both their numbers and assets. Second, the share of insurance in Gross Domestic Product (GDP) is considerable, in excess of $10 \%$ in developed economies. Third, the development of insurance markets affects economic growth and development, chiefly by compensating for effects of random losses, but also through its benefits to businesses and entire national economies. Insurance companies have large cash inflows and reserves, which may be partly invested in less liquid instruments like bonds and equity. In this context, the development of insurance services plays an important role in financial markets' development through risk management, savings allocation, and market growth. Insurance markets of individual countries develop under the influence of various factors, which are divided into economic, demographic, social, and cultural. Scholars treat the share of foreign insurance companies as one of structural factors. Research into this subject was conducted, among others, by Outreville (1990, pp. 487-498; 1996, pp. 263-278), Moshirian (1997, pp. 159-173; 1999, pp. 34-49), Li et al. (2007, pp. 637-652), Dickinson (2000, pp. 10-18), Ma and Pope (2003, pp. 235-248), Carson et al. (2014, pp. 1-15), Bukowski and Lament (2019, pp. 33-45). They do not confirm the unambiguous influence of foreign capital on the development of insurance markets. The effect commonly appears only in life insurance companies, e.g. Outreville (1990, pp. 487-498; 1996, pp. 263-278) and Carson et al. (2014, pp. 1-15).

The analysis of dependencies between foreign capital and development of the insurance market in EU-15 countries is the prime objective of research presented in this paper. This required us to find answers to the following research questions:

- What factors determine the development of insurance markets?

- Does foreign capital influence the development of insurance markets?

In search of answers and in order to verify the research hypothesis, we will undertake a critical review of literature, analyse contents of factors that influence the development of insurance markets, and employ econometric methods. Next, we will construct a panel model and analyse results of its estimation. The share of foreign capital is treated as one of independent variables that influence the development of the insurance markets measured with insurance penetration rate and with the ratio of insurance density. Moreover, the following factors are assumed to affect the development of insurance markets (explanatory variables): market size (measured with the number of insurance companies) and structure (measured with the share of life insurance companies in the total number of insurance companies).

We will use annual data concerning insurance markets of EU-15 countries from 1999-2016 provided by the OECD.

This study will contribute to the development of theories concerning factors of the development of insurance markets.

The remainder of this study is structured as follows: first part of the article presents a review of specialist literature, second part describes the material and methods, third part reports on empirical findings, and fourth part discusses the findings. 


\section{LITERATURE REVIEW}

Development is a process of transformations or changes in a variety of areas that involve shifts towards conditions or forms that are more complex or in some respects more perfect. Its general objective may comprise qualitative and quantitative changes. As far as the insurance market is concerned, it may denote more transactions or revenue (quantitative changes) and efficiency enhanced by way of improvements to the market, insurers, and their insurance products (qualitative changes). Therefore, it is a complex and multi-dimensional process, which should lead to long-term economic and socio-economic growth (e.g. Owsiak, 2002, pp. 34-45; Pelegrin et al., 2002, pp. 4-13; Levin, 1997, pp. 688-726). Insurance markets of individual countries develop under the influence of diverse factors. Authors commonly indicate three factor classes that affect the insurance market: economic (GDP, employment, inflation, etc.), demographic (age, gender, education, etc.), and social (aversion to risk, education, religion, etc.). This is corroborated by Sen and Madheswaran (2013, pp. 86-103), Sen (2007, pp. 3-8), Hwang and Greenford (2005, pp. 103-125), Zietz (2003, pp. 159-191), and Beck and Webb (2003, pp. 51-88), among others.

The economic development of a country is among the crucial factors that affect the development of insurance markets. It provides for adequate economic and financial levels, including standards of living. Adequate living standards contribute to greater levels of wealth, education, and demand for insurance, since financial resources accumulate which, in turn, translates into the economic growth of a country. According to the European Bank for Reconstruction and Development (EBRD) Transition Report 2018-19 (EBRD, 2019, p. 96) growth was broadly based in that period, with support provided by stronger investment activity and increases in exports. In the longer term, growth trajectories of countries in the EBRD regions are - to a large extent - shaped by those countries' demographic profiles. Some EBRD regions have similar rates of real output growth, despite considerably differing in terms of growth in per capita income and underlying growth in output per worker.

Kurylo et al. (2017, pp. 12-28) believe the development of insurance markets is driven by: improved competition, capitalisation, and concentration of insurers' funds; the emergence, introduction, and propagation of new, innovative types of insurance and reinsurance; the application of innovative technologies, mergers of insurance, banking, and financial capitals; and the adjustment of national insurance markets to established principles of international trade. Factors associated with the behaviour of insurance company customers are also important, primarily evolving approaches to the need for insurance protection, as affirmed by Wieczorek-Kosmala (2016, pp. 109-125). Burić et al. (2017, pp. 24-32) claim it is necessary to educate the public, develop insurance culture, and encourage a sense of individual responsibility for financial, personal, and family security by various forms of saving, including life insurance policies.

The development of insurance is also seen as part of a broader economic category of financial development, one of structural factors. This factor fosters the development of insurance with regard to both supply and demand (Bednarczyk, 2012, p. 101). This positive relationship between insurance consumption and the size of a financial sector is confirmed by Outreville (1990, pp. 487-498; 1996, pp. 263-278), Ward and Zurbruegg (2000, pp. 489506), Beck and Webb (2003, pp. 51-88), Arena (2008, pp. 921-946), among others. Structural factors of insurance market development also comprise market monopolisation, the 
presence of foreign firms, market concentration, the degree of market openness, the standard of social security, legal system, the enforcement of property rights, and political risk. The involvement of foreign insurers is regarded as another structural factor. This field was studied by Outreville (1990, pp. 487-498; 1996, pp. 263-278), Moshirian (1997, pp. 159-173; 1999, pp. 34-49), Li et al. (2007, pp. 637-652), Dickinson (2000, pp. 10-18), Ma and Pope (2003, pp. 235248), and Carson et al. (2014, pp. 1-15), among others. All of the above scholars fail to affirm the impact of foreign capital on the development of insurance markets. Foreign participation affects selected groups of markets, e.g. in developing countries, or segments of the insurance market, e. g. life insurance or property and liability insurance. This influence is most commonly noted only in life insurance companies, e.g. Outreville (1990, pp. 487-498; 1996, pp. 263-278) and Carson et al. (2014, pp. 1-15). However, according Bukowski and Lament (2019, pp. 3345), Visegrad Group countries with higher foreign investment tend to have a higher insurance penetration in property and personal insurance companies.

Therefore, we formulate our research hypothesis:

$\mathbf{H}$ : The share of foreign capital in insurance sector is an important factor of insurance market development in EU-15 countries.

In statistical terms (e.g. GUS - Statistics Poland, PIU - Polish Insurance Association, KNF - Polish Financial Supervision Authority), the development of an insurance market is normally measured with values and growth dynamics of gross written premium and rates of insurance density (gross written premium/population) and penetration (gross written premium/GDP). This is reaffirmed by Browne and Kim (1993, pp. 616-634), Beck and Webb (2003, pp. 51-88), Zhang and Zhu (2005, pp. 1-14), Pye (2005, pp. 205-223), Li et al. (2007, pp. 637-652), Chui and Kwok (2008, pp. 88-101), Zheng et al. (2009, pp. 85-99), Cristian (2010, pp. 504-508), Han et al. (2010, pp. 183-199), Sankaramuthukumar and Alamelu (2012, pp. 27-47), Medved' and Kavčič (2012, pp. 105-120), Bednarczyk (2012, pp. 67-78), Brokešová and Vachálková (2016, pp. 63-72), Kurylo et al. (2017, pp. 12-28), Burić et al. (2017, pp. 24-32), and Bukowski and Lament (2019, pp. 33-45).

The analysis of these factors helps to identify the historical differences and cultural conditions that influence the development of insurance markets in particular countries. We should note prevailing legal and systemic solutions have a substantial impact on both the development of insurance markets and values of mentioned metrics; we mean here the extent of compulsory insurance and its share in total written premium and national insurance systems that encourage resorting to personal life assurance, which protects against risks of sickness and old age. The penetration rate evaluates the relative significance of insurance sectors in national economies as they evolve. The penetration rate represents the weight of insurance sector in a country's economy. However, its sensitivity to GDP development is a weakness. This means the penetration rate may greatly vary following dramatic changes in GDP, even if an insurance market does not experience major shifts in the same period (Brokešová \& Vachálková, 2016, pp. 66-68). The rate of insurance density reflects the population of a given country, a major determinant of demand for insurance products. Thus, it represents the real growth of insurance. Both these rates are essential to comparisons of insurance development among countries. The relationship between the development of insurance markets and the economic development of countries is illustrated with Enz's 'Scurve' that represents the dependence between rates of insurance penetration and per capita GNP (Enz 2000, pp. 396-406, Bednarczyk 2012, p. 115-126). 
Levine (2004, pp. 15-18) argues financial systems in each country provide same functions, although sometimes in different ways. The quality with which individual systems fulfil these functions depends on the standard of a financial system's development, its effectiveness, and structure. In view of the foregoing, the development of insurance markets in particular countries varies depending on:

- the level of its development measured as numbers of insurance companies,

- the structure of an insurance market measured as share of life insurers and foreign capital,

- the effectiveness of an insurance market and its significance in a national economy, measured as rates of insurance density and penetration.

\section{MATERIAL AND METHODS}

We addressed the research problem of the relationship between the development of insurance markets and the share of foreign capital in equity of insurance companies. We studied a homogenous group of insurance markets, EU-15, regarded as high-income countries. The following measures of insurance market development (explained variables) are adopted:

- penetration rate (written premiums/GDP), which measures the total revenue of insurance companies and shows the importance of insurance in a national economy and indicates the development of insurance and demand for insurance products,

- the ratio of insurance density (written premiums per inhabitant), which reflects the population of a country, a major determinant of demand for insurance products.

The following (explanatory variables) are assumed to affect the development of insurance markets:

- market size, measured with numbers of insurance companies; the size of the insurance sector is significantly related to the level of development and the size of financial sector in specialist literature, e.g. Outreville (1990, pp. 487-498), Ward and Zurbruegg (2002, pp. 489-506), Li et al. (2007, pp. 637-652); it is hypothesised that market size has a positive impact on the development of insurance markets,

- the structure of an insurance market, measured with the share of life insurance companies in the total number of insurers; it is hypothesised that the larger the share of life insurance companies, the more positive impact on development of an insurance market; studies in this field were conducted by, among others, Haiss and Sümegi (2008, pp. 405-431) and Arena (2008, pp. 921-946),

- the share of foreign capital in the equity of insurance companies; it has been established for life and non-life insurance companies; it is hypothesised that foreign capital has positive impact on the development of insurance markets. Studies in this area were conducted by, e.g. Moshirian (1997, pp. 159-173, 1999, pp. 34-49), Dickinson (2000, pp. 10-18), Ma and Pope (2003, pp. 235-248), Carson et al. (2014, pp. 1-15), Bukowski and Lament (2019, pp. 33-45).

We used annual data concerning insurance markets of EU-15 countries from 19992016 published in the OECD's Insurance Statistics Yearbook and the OECD's Business and Finance Outlook (2008, 2011, 2015, 2016, and 2017). We built the following panel data models for the purpose of verifying our hypothesis: 
Model 1:

$$
R P_{i, t}=a_{1 i, t}+a_{2 i, t} P_{i, t}+a_{3 i, t} L_{i, t}+a_{4 i, t} S I_{i, t}+a_{5 i, t} N i_{i, t}+u_{i, t}
$$

Model 2:

where:

$$
\ln D I_{i, t}=a_{1 i, t}+a_{2 i, t} P_{i, t}+a_{3 i, t} L_{i, t}+a_{4 i, t} S I_{i, t}+a_{5 i, t} N i_{i, t}+u_{i, t}
$$

$R P_{i, t}$ - penetration rate (written premiums/GDP);

$D I_{i, t}$ - the ratio of insurance density (written premiums per inhabitant);

$P_{i, t}$ - the share of foreign property insurance companies in equity capital of all insurance companies;

$L_{i, t}$ - the share of foreign life insurance companies in the equity capital of all insurance companies;

$S I_{i, t}$ - the share of life insurance companies in the total number of insurance companies;

$N i_{i, t}$ - the total number of insurance companies;

Ln - natural logarithm;

$u_{i, t}$ - random factor.

\section{RESULTS}

Basic statistics concerning the variables studied are shown in Table 1.

Table 1. Basic statistics concerning the variables studied from EU-15 countries in 1999-2016

\begin{tabular}{|l|c|c|c|c|c|c|}
\hline Specification & $\boldsymbol{R P}$ & $\boldsymbol{D I}$ & $\boldsymbol{P}$ & $\boldsymbol{L}$ & SI & Ni \\
\hline \multicolumn{7}{|c|}{ Austria } \\
\hline Average & 0.053915 & 2374.462 & 0.392600 & 0.303185 & 0.378869 & 49.38462 \\
\hline Median & 0.054000 & 2228.000 & 0.396500 & 0.322000 & 0.387400 & 52.00000 \\
\hline Minimum & 0.047800 & 2061.000 & 0.352100 & 0.135200 & 0.324500 & 39.00000 \\
\hline Maximum & 0.057600 & 2741.000 & 0.433900 & 0.393100 & 0.417300 & 54.00000 \\
\hline \multicolumn{7}{|c|}{ Belgium } \\
\hline Average & 0.081631 & 3390.385 & 0.024046 & 0.018231 & 0.646415 & 141.5385 \\
\hline Median & 0.080000 & 3484.000 & 0.026300 & 0.017800 & 0.648100 & 148.0000 \\
\hline Minimum & 0.063000 & 2612.000 & 0.007200 & 0.016800 & 0.543800 & 117.0000 \\
\hline Maximum & 0.112600 & 4011.000 & 0.028700 & 0.019900 & 0.755500 & 171.0000 \\
\hline \multicolumn{7}{|c|}{ Denmark } \\
\hline Average & 0.094500 & 5224.615 & 0.207962 & 0.169369 & 0.689223 & 180.3846 \\
\hline Median & 0.096000 & 5609.000 & 0.183400 & 0.185500 & 0.677100 & 184.0000 \\
\hline Minimum & 0.070400 & 3174.000 & 0.144700 & 0.025000 & 0.584700 & 153.0000 \\
\hline Maximum & 0.106000 & 6572.000 & 0.282600 & 0.204000 & 0.954100 & 202.0000 \\
\hline \multicolumn{7}{|c|}{ Finland } \\
\hline Average & 0.040392 & 1826.000 & 0.167485 & 0.376838 & 0.516054 & 91.76923 \\
\hline Median & 0.037600 & 1739.000 & 0.238100 & 0.376300 & 0.505600 & 92.00000 \\
\hline Minimum & 0.032800 & 1361.000 & 0.004700 & 0.343200 & 0.452600 & 48.00000 \\
\hline Maximum & 0.051000 & 2546.000 & 0.250100 & 0.431100 & 0.595100 & 136.0000 \\
\hline
\end{tabular}




\begin{tabular}{|c|c|c|c|c|c|c|}
\hline Specification & $R P$ & DI & $P$ & $L$ & SI & $\mathrm{Ni}$ \\
\hline \multicolumn{7}{|c|}{ France } \\
\hline Average & 0.099677 & 4086.538 & 0.001669 & 0.032492 & 0.628723 & 375.0769 \\
\hline Median & 0.095400 & 4172.000 & 0.001000 & 0.008900 & 0.624200 & 381.0000 \\
\hline Minimum & 0.086000 & 3246.000 & 0.001000 & 0.004700 & 0.598100 & 301.0000 \\
\hline Maximum & 0.124100 & 4785.000 & 0.003000 & 0.176500 & 0.667200 & 473.0000 \\
\hline \multicolumn{7}{|c|}{ Greece } \\
\hline Average & 0.021817 & 497.0000 & 0.282762 & 0.440354 & 0.465308 & 72.38462 \\
\hline Median & 0.021800 & 511.0000 & 0.345000 & 0.538000 & 0.472100 & 58.00000 \\
\hline Minimum & 0.020050 & 356.0000 & 0.045800 & 0.090000 & 0.414200 & 45.00000 \\
\hline Maximum & 0.024000 & 616.0000 & 0.573100 & 0.769000 & 0.504500 & 113.0000 \\
\hline \multicolumn{7}{|c|}{ Spain } \\
\hline Average & 0.053300 & 1538.846 & 0.238031 & 0.144162 & 0.445862 & 281.0769 \\
\hline Median & 0.054200 & 1518.000 & 0.222000 & 0.122700 & 0.441500 & 287.0000 \\
\hline Minimum & 0.050100 & 1294.000 & 0.170000 & 0.037100 & 0.407700 & 231.0000 \\
\hline Maximum & 0.056000 & 1801.000 & 0.338600 & 0.519100 & 0.476100 & 332.0000 \\
\hline \multicolumn{7}{|c|}{ Netherlands } \\
\hline Average & 0.069854 & 3225.231 & 0.197777 & 0.217677 & 0.502123 & 273.4615 \\
\hline Median & 0.065000 & 3484.000 & 0.185600 & 0.225000 & 0.511200 & 282.0000 \\
\hline Minimum & 0.047000 & 2170.000 & 0.116000 & 0.046000 & 0.435400 & 186.0000 \\
\hline Maximum & 0.099000 & 3776.000 & 0.294000 & 0.293800 & 0.561500 & 368.0000 \\
\hline \multicolumn{7}{|c|}{ Ireland } \\
\hline Average & 0.193900 & 9960.692 & 0.141777 & 0.002146 & 0.650215 & 276.0000 \\
\hline Median & 0.195200 & 9820.000 & 0.131600 & 0.002200 & 0.663700 & 266.0000 \\
\hline Minimum & 0.164600 & 8127.000 & 0.073600 & 0.000400 & 0.491100 & 217.0000 \\
\hline Maximum & 0.238600 & 11284.00 & 0.243000 & 0.002900 & 0.835900 & 355.0000 \\
\hline \multicolumn{7}{|c|}{ Luxemburg } \\
\hline Average & 0.373977 & 39246.92 & 0.548477 & 0.876992 & 0.917785 & 336.4615 \\
\hline Median & 0.346700 & 36262.00 & 0.533000 & 0.951000 & 0.915200 & 343.0000 \\
\hline Minimum & 0.274900 & 22130.00 & 0.378200 & 0.625600 & 0.893900 & 297.0000 \\
\hline Maximum & 0.520000 & 57520.00 & 0.645000 & 0.972100 & 0.943100 & 368.0000 \\
\hline \multicolumn{7}{|c|}{ Germany } \\
\hline Average & 0.066085 & 2656.000 & 0.150177 & 0.236546 & 0.396146 & 487.3846 \\
\hline Median & 0.065800 & 2588.000 & 0.145000 & 0.260000 & 0.379300 & 489.0000 \\
\hline Minimum & 0.061200 & 2390.000 & 0.080000 & 0.106800 & 0.331400 & 364.0000 \\
\hline Maximum & 0.073000 & 3129.000 & 0.195200 & 0.301000 & 0.479100 & 740.0000 \\
\hline \multicolumn{7}{|c|}{ Portugal } \\
\hline Average & 0.074692 & 1550.462 & 0.433046 & 0.205715 & 0.672315 & 77.92308 \\
\hline \begin{tabular}{|l|} 
Median \\
\end{tabular} & 0.078000 & 1565.000 & 0.323800 & 0.072400 & 0.674600 & 78.00000 \\
\hline Minimum & 0.055900 & 1109.000 & 0.265000 & 0.058100 & 0.588400 & 70.00000 \\
\hline Maximum & 0.089200 & 2086.000 & 0.909600 & 0.774600 & 0.746100 & 86.00000 \\
\hline \multicolumn{7}{|c|}{ Sweden } \\
\hline Average & 0.061631 & 2956.692 & 0.521546 & 0.162823 & 0.553300 & 212.5385 \\
\hline Median & 0.059900 & 2793.000 & 0.519000 & 0.173000 & 0.522100 & 207.0000 \\
\hline Minimum & 0.042000 & 2388.000 & 0.448400 & 0.048300 & 0.467100 & 192.0000 \\
\hline Maximum & 0.083100 & 3960.000 & 0.638000 & 0.326800 & 0.749200 & 245.0000 \\
\hline
\end{tabular}




\begin{tabular}{|l|c|c|c|c|c|c|}
\hline Specification & $\boldsymbol{R P}$ & $\boldsymbol{D I}$ & $\boldsymbol{P}$ & $\boldsymbol{L}$ & SI & Ni \\
\hline \multicolumn{7}{|c|}{ The United Kingdom } \\
\hline Average & 0.132108 & 5480.385 & 0.515462 & 0.297485 & 0.711385 & 488.5385 \\
\hline Median & 0.129000 & 5255.000 & 0.531000 & 0.233000 & 0.732600 & 503.0000 \\
\hline Minimum & 0.092100 & 3724.000 & 0.380900 & 0.160000 & 0.617900 & 328.0000 \\
\hline Maximum & 0.191600 & 8967.000 & 0.580000 & 0.569600 & 0.760600 & 552.0000 \\
\hline \multicolumn{7}{|c|}{ Italy } \\
\hline Average & 0.130046 & 2512.923 & 0.302492 & 0.298700 & 0.686669 & 236.4615 \\
\hline Median & 0.075000 & 2442.000 & 0.300000 & 0.301000 & 0.671100 & 241.0000 \\
\hline Minimum & 0.060700 & 2212.000 & 0.259000 & 0.237500 & 0.591500 & 214.0000 \\
\hline Maximum & 0.797000 & 3089.000 & 0.348400 & 0.376500 & 0.778200 & 247.0000 \\
\hline
\end{tabular}

Source: own elaboration based on OECD data (OECD, 2008, 2011, 2015, 2016, 2017).

The models estimated by between groups fit are relatively good. In the case of Model 1 , the coefficient of determination equals 0.8 and - in the case of Model 2-0.63. The results of models' estimation are presented in Table 2 and in Table 3 below.

Table 2. Model 1: between-groups, using observations 1-15; dependent variable: RP

\begin{tabular}{|l|c|c|c|c|c|}
\hline Specification & Coefficient & Std. Error & t-ratio & $\boldsymbol{p}$-value & \\
\hline Const & -0.190735 & 0.0511440 & -3.729 & 0.0039 & $* * *$ \\
\hline $\mathrm{P}$ & -0.0188705 & 0.0846027 & -0.2230 & 0.8280 & \\
\hline $\mathrm{L}$ & 0.134637 & 0.0693916 & 1.940 & 0.0810 & $*$ \\
\hline $\mathrm{SI}$ & 0.399400 & 0.0887818 & 4.499 & 0.0011 & $* * *$ \\
\hline $\mathrm{Ni}$ & 0.000111798 & $7.16861 \mathrm{e}-05$ & 1.560 & 0.1499 & \\
\hline Mean dependent var & 0.099623 & \multicolumn{2}{l|}{ S.D. dependent var } & 0.078498 \\
\hline Sum squared reside & 0.016864 & \multicolumn{2}{l|}{ S.E. of regression } & 0.041066 \\
\hline $\mathrm{R}$-squared & 0.804509 & Adjusted R-squared & 0.726313 \\
\hline $\mathrm{F}(4,10)$ & 10.28832 & P-value(F) & 0.001434 \\
\hline Log-likelihood & 29.64544 & Akaike criterion & -49.29088 \\
\hline Schwarz criterion & -45.75062 & Hannan-Quinn & -49.32859 \\
\hline
\end{tabular}

*** The variable is significant at the level of 0.01 .

$* *$ The variable is significant at the level of 0.05 .

* The variable is significant at the level of 0.1 .

Source: own elaboration based on OECD data (OECD, 2008, 2011, 2015, 2016, 2017).

In the case of insurance market development measured with the ratio of insurance penetration $(R P)$, only variables $(S I)$ and $(L)$ are statistically significant; that is, respectively, the share of life insurance companies in the total number of insurance companies and the share of foreign life insurance companies in equity capital of all insurance companies (see Table 2).

In respect of another measure of insurance market development - the ratio of insurance density ( $D I$; written premium per inhabitant) - the share of life insurance companies in the total number of insurance companies $(S I)$ is statistically significant (see Table 3). In order to strengthen the results of analysis, we also used estimation by means of Groupwise Weighted Least Square (WLS). The results of models' estimation are presented in Table 4 and in Table 5. 
Table 3. Model 2: between-groups, using observations 1-15. Dependent variable: In_DI

\begin{tabular}{|l|c|c|c|c|c|}
\hline Specification & Coefficient & Std. Error & t-ratio & p-value & \\
\hline Const & 4.64979 & 0.834642 & 5.571 & 0.0002 & $* * *$ \\
\hline $\mathrm{P}$ & -0.0393014 & 1.38067 & -0.02847 & 0.9779 & \\
\hline $\mathrm{L}$ & 0.424242 & 1.13243 & 0.3746 & 0.7158 & \\
\hline $\mathrm{SI}$ & 4.54426 & 1.44887 & 3.136 & 0.0106 & $* *$ \\
\hline $\mathrm{Ni}$ & 0.00199247 & 0.00116988 & 1.703 & 0.1194 & \\
\hline Mean dependent var & 7.920729 & \multicolumn{2}{l|}{ S.D. dependent var } & 0.943714 \\
\hline Sum squared reside & 4.491395 & \multicolumn{2}{l|}{ S.E. of regression } & 0.670179 \\
\hline $\mathrm{R}$-squared & 0.639777 & Adjusted R-squared & 0.495687 \\
\hline F(4, 10) & 4.440137 & P-value(F) & 0.025468 \\
\hline Log-likelihood & -12.23993 & Akaike criterion & 34.47985 \\
\hline Schwarz criterion & 38.02010 & Hannan-Quinn & 34.44214 \\
\hline
\end{tabular}

*** The variable is significant at the level of 0.01 .

** The variable is significant at the level of 0.05 .

* The variable is significant at the level of 0.1 .

Source: own elaboration based on OECD data (OECD, 2008, 2011, 2015, 2016, 2017).

Table 4. Model 1: WLS, using 270 observations; included 15 cross-sectional units; dependent variable: RP; weights based on per-unit error variances

\begin{tabular}{|l|c|c|c|c|c|}
\hline Specification & Coefficient & St . Error & t-ratio & $\boldsymbol{p}$-value & \\
\hline Const & -0.0892728 & 0.00884470 & -10.09 & $<0.0001$ & $* * *$ \\
\hline $\mathrm{P}$ & -0.0157628 & 0.0118308 & -1.332 & 0.1839 & \\
\hline $\mathrm{L}$ & 0.0750934 & 0.0128528 & 5.843 & $<0.0001$ & $* * *$ \\
\hline $\mathrm{SI}$ & 0.241384 & 0.0130603 & 18.48 & $<0.0001$ & $* * *$ \\
\hline $\mathrm{Ni}$ & $8.61991 \mathrm{e}-05$ & $8.86194 \mathrm{e}-06$ & 9.727 & $<0.0001$ & $* * *$ \\
\hline \multicolumn{5}{|l|}{ Statistics based on the weighted data: } \\
\hline Sum squared resid & 196.6321 & S.E. of regression & 0.861399 \\
\hline $\mathrm{R}$-squared & 0.583003 & Adjusted R-squared & 0.576709 \\
\hline F(4, 265) & 92.62400 & P-value(F) & $3.64 \mathrm{e}-49$ \\
\hline Log-likelihood & -340.3066 & Akaike criterion & 690.6132 \\
\hline Schwarz criterion & 708.6053 & Hannan-Quinn & 697.8380 \\
\hline \multicolumn{5}{|l|}{ Statistics based on the original data: } \\
\hline Mean dependent var & 0.099623 & S.D. dependent var & 0.090432 \\
\hline Sum squared resid & 1.147905 & S.E. of regression & 0.065816 \\
\hline
\end{tabular}

*** The variable is significant at the level of 0.01 .

** The variable is significant at the level of 0.05 .

* The variable is significant at the level of 0.1 .

Source: own elaboration based on OECD data (OECD, 2008, 2011, 2015, 2016, 2017).

The analysis of Tables 4 and 5 shows that the explanatory variables are statistically significant except for variable $(P)$ : the share of foreign property insurance companies in equity capital of all insurance companies. 
Table 5. Model 2: WLS, using 270 observations; included 15 cross-sectional units; dependent variable: In_DI; weights based on per-unit error variances

\begin{tabular}{|l|c|c|c|c|c|}
\hline Specification & Coefficient & Std. Error & t-ratio & $p$-value & \\
\hline const & 5.52839 & 0.153973 & 35.90 & $<0.0001$ & $* * *$ \\
\hline $\mathrm{P}$ & 0.113824 & 0.195021 & 0.5836 & 0.5600 & \\
\hline $\mathrm{L}$ & 0.793680 & 0.190345 & 4.170 & $<0.0001$ & $* * *$ \\
\hline $\mathrm{SI}$ & 3.27658 & 0.242244 & 13.53 & $<0.0001$ & $* * *$ \\
\hline $\mathrm{Ni}$ & 0.00110849 & 0.000190156 & 5.829 & $<0.0001$ & $* * *$ \\
\hline \multicolumn{5}{|}{ Statistics based on the weighted data: } \\
\hline Sum squared resid & 254.7018 & S.E. of regression & 0.980377 \\
\hline $\mathrm{R}$-squared & 0.503942 & Adjusted R-squared & 0.496454 \\
\hline F(4, 265) & 67.30285 & P-value(F) & $3.08 \mathrm{e}-39$ \\
\hline Log-likelihood & -375.2390 & Akaike criterion & 760.4781 \\
\hline Schwarz criterion & 778.4702 & Hannan-Quinn \\
\hline \multicolumn{5}{|}{ Statistics based on the original data: } \\
\hline Mean dependent var & 7.920729 & S.D. dependent var \\
\hline Sum squared resid & 124.8640 & S.E. of regression & 0.965187 \\
\hline
\end{tabular}

$* * *$ The variable is significant at the level of 0.01 .

** The variable is significant at the level of 0.05 .

* The variable is significant at the level of 0.1 .

Source: own elaboration based on OECD data (OECD, 2008, 2011, 2015, 2016, 2017).

\section{DISCUSSION}

The analysis of our research shows that the development of the EU-15 insurance markets in the period studied was affected by: the structure of insurance market measured with the share of life insurance companies (variable $S /$ ), the share of foreign capital in life insurance companies (variable $L$ ), and the number of insurance companies (variable $\mathrm{Ni}$ ). It means that life insurance companies influence the development of EU-15 insurance market more than non-life insurers. Life insurance plays an important role in mobilising savings. Demand for life insurance is strongly correlated with rates of savings and per capita disposable income. The greater the tendency to save and household incomes, the higher the demand for and development of life insurance. Countries with larger shares of life insurers in structures of insurance markets exhibit greater rates of penetration. This agrees with studies by Haiss and Sümegi (2008, pp. 405-431) and Arena (2008, pp. 921-946). They demonstrate that life insurance is more important for high-income countries, whereas property-liability insurance is more important for emerging and developing countries. Research by Bukowski and Lament (2019, pp. 33-45) shows that life insurance is more importanty in Visegrad Group countries. These results are contested by Han et al. (2010, pp. 183-199), who show that both sectors play a much more important role in emerging than they do in developed countries. Some studies of insurance development acknowledge the heterogeneity problem and as a solution propose the separation of developing from developed countries, e.g. Outreville (1996, pp. 263-278), Beck and Webb (2003, pp. 51-88), and Li et al. (2007, pp. 637-652), Carson et al. (2014, pp. 1-15). Our article considers the 
insurance markets of EU-15 countries, treated as high-income countries. Our research upheld earlier results, namely the greater significance of life insurance companies to the development of insurance markets in these countries.

The internationalisation of insurance services plays an important role - both direct and indirect - in the development process. Direct impact is linked to the modification of composition of the supply of funds to an economy: the relative supply of funds increases in the long term, which translates into increased demand for financial instruments, e.g. insurance products. Indirect impact consists in more institutional investors who - by means of innovative solutions - contributed to improved market efficiency by the specialisation of both financial intermediaries and the corporate sector, among other ways (Dickinson, 2000, pp. 10-18). According to Ma and Pope (2003, pp. 235-248) foreign participation in non-life insurance markets influences market competition and market liberalisation. Moshirian (1997, pp. 159-173; 1999, pp. 34-49) concludes that demand for insurance services and the size of insurance sector of a source country, among other factors, significantly influence the level of foreign investment in life insurance. Carson et al. (2014, pp. 12-15) suggest that developing countries with higher foreign investment tend to have a higher life insurance penetration. This is corroborated by our own results as well. Our results imply that the development of EU-15 countries' insurance markets is influenced by shares of foreign capital in life insurance companies (Model 1 in Table 2 and 4). Model 1 assumes penetration rate while Model 2 (Table 3 and 5) the ratio of insurance density as the dependent variable. The penetration rate was principally addressed in earlier studies of effects of foreign investments on insurance markets' development, e.g. Carson et al. (2014, pp. 1-15), Sawadogo and Guèrineau (2015, pp. 1-10), Bukowski and Lament (2019, pp. 33-45). Thus, our research expands the analysis of how foreign investments affect the development of EU-15 insurance markets with the ratio of insurance density (Model 2). The results further reinforce results of Model 1 estimation, pointing to the greater significance of life insurance companies to the development of insurance markets in high-income countries. Therefore, measured with the share of life insurance companies in overall number of insurance companies and the share of foreign life insurance companies in equity capital of total insurers' equity, market structure has a substantial impact on the development of the EU-15 insurance markets.

\section{CONCLUSIONS}

The critical review of specialist literature and the analysis of our research results into insurance markets of EU-15 countries in 1999-2016 enabled us to answer the research question and verify the hypothesis. The literature review demonstrated that the development of insurance markets is determined by a variety of factors: macroeconomic, cultural, and social. Economic (e.g. GNP, employment), demographic (age, gender), and social (education, the development of insurance culture) factors are studied most frequently. The involvement of foreign capital in insurance companies is treated as a structural factor. Research fails to unambiguously corroborate that the participation of international capital affects development of insurance markets. This effect normally applies only to life insurance companies, e.g. Outreville (1990, pp. 487-498; 1996, pp. 263-278) and Carson et al. (2014, pp. 1-15).

The analysis of our study of EU-15 countries in 1999-2016 proved that the development of insurance markets measured with penetration rate (Model 1) is determined by 
the share of foreign capital in life insurance companies $(L)$, by the share of life insurers in overall numbers of insurance companies $(S I)$, and by the number of insurance companies (Ni). This partly means - only in respect of life insurers - that the share of foreign capital affected the development of studied insurance markets. This helps to verify our research hypothesis. The development of insurance markets as measured with the penetration rate (Model 1) is also affected by the share of life insurers in overall numbers of insurance companies. This means that the development of examined insurance markets was affected by insurance market structure.

The analysis of our study proved that the development of insurance markets - measured with the ratio of insurance density (Model 2) - is affected by the share of life insurance companies in the total number of insurance companies $(S I)$, the share of foreign capital in life insurance companies $(L)$, and the number of insurance companies $(\mathrm{Ni})$.

Therefore, the verification of hypotheses concerning the impact of foreign capital on development of insurance markets requires further studies of another group of countries (insurance markets). This will be the subject matter of our future research.

The above research results reinforce research on the development of theories concerning factors in the development of insurance markets. Nevertheless, more research is needed to examine the impact of macro- and microeconomic factors in the development of insurance markets that operate in different parts of the world. This would broaden the scope of insurance markets research in different parts of the world and improve methodology by selecting diverse metrics of panel model data.

\section{REFERENCES}

Arena, M. (2008). Does insurance market promote economic growth? A cross-country study for industrialized and developing countries. Journal of Risk and Insurance, 75(4), 921-946. https://doi.org/10.1111/j.1539-6975.2008.00291.x

Beck, T., \& Webb, I. (2003). Economic, demographic, and institutional determinants of life insurance consumption across countries. World Bank Economic Review, 17(1), 51-88.

Bednarczyk, T. (2012). Wpływ działalności sektora ubezpieczeniowego na wzrost gospodarczy. Lublin: Wydawnictwo Uniwersytetu Marii Curie-Skłodowskiej.

Bukowski, S., \& Lament, M. (2019). Impact of foreign capital on the insurance market development in the Visegrad Group countries. Journal of Management and Financial Sciences, 38, 33-45.

Brokešová, Z., \& Vachálková, I. (2016). Macroeconomic environment and insurance industry development: The case of Visegrad group countries. Central European Review of Economic Issues. Economická Revue, 19, 63-72.

Browne, M.J., \& Kim, K. (1993). An international analysis of life insurance demand. The Journal of Risk and Insurance, 60(4), 616-634. https://doi.org/10.2307/253382

Burić, M.N., Smolović, J.C., Božović, M.L., \& Filipović, A. L. (2017). Impact of economic factors on life insurance development in Western Balkan Countries. Zbornik radova Ekonomskog fakulteta $u$ Rijeci : časopis za ekonomsku teoriju i praksu, 35(2), 24-32.

Carson, J.M., Chen, P.H., \& Outreville, J.F. (2014). Does foreign direct investment affect the supply of life insurance in developing countries?. Retrieved from http://citeseerx.ist.psu.edu/viewdoc/download?doi=10.1.1.684.9911\&rep=rep1\&type=pdf on June 5, 2018.

Chui, A.C., \& Kwok, C.C. (2008). National culture and life insurance consumption. Journal of International Business Studies, 39(1), 88-101. https://doi.org/10.1057/palgrave.jibs.8400316 
Cristian, B.C. (2010). Current coordinates of the Romanian insurance sector. Annals of Faculty of Economics, 1(2), 504-508.

Dickinson, G. (2000). Encouraging a dynamic life insurance industry: economic benefits and policy issues. London: Center for insurance and investment studies. Retrieved from www.oecd.org. on June 5, 2018.

EBRD (2019). Transition Report 2018-19.

Enz, R. (2000). The S-curve relation between per-capita income and insurance penetration. The Geneva Papers and Insurance, 25(3), 396-406. https://doi.org/10.1111/1468-0440.00072

Haiss, P., \& Sümegi, K. (2008). The relationship between insurance and economic growth in Europe: a theoretical and empirical analysis. Empirica, 35(4), 405-431. https://doi.org/ 10.1007/s10663008-9075-2

Han, L., Li, D., Moshirian, F., \& Tian, Y. (2010). Insurance development and economic growth. Geneva Papers on Risk and Insurance, 35(1), 183-199. https://doi.org/10.1057/gpp.2010.4

Hwang, T., \& Greenford, B. (2005). A cross-section analysis of the determinants of life insurance consumption in Mainland China, Hong Kong, and Taiwan. Risk Management and Insurance Review, 8(1), 103-125. https://doi.org/10.1111/j.1540-6296.2005.00051.x

Kurylo, V., Kurylo, L., Zhovnirchyk, Y., Kartashov, Y., \& Sokol, S. (2017). The development of the insurance market of Ukraine amid the global trends in insurance. Investment Management and Financial Innovations, 14(1), 213-225. https://doi.org/ 0.21511/imfi.14(1-1).2017.07

Levine, R. (2004). Finance and growth: theory and evidence (NBER Working Papers, 10766). National Bureau of Economic Research, Cambridge.

Levine, R. (1997). Financial development and economic growth: views and agenda. Journal of Economic Literature, 35(2), 688-726.

Li, D., Moshirian, F., Nguyen, P., \& Wee, T. (2007). The demand for life insurance in OECD countries. Journal of Risk and Insurance, 74(3), 637-652. https://doi.org/10.1111/j.15396975.2007.00228.x

Ma, Y.L., \& Pope, N. (2003). Determinants of international insurer's participation in foreign non-life markets. Journal of Risk and Insurance, 70(2), 235-248. https:/doi.org/10.1111/15396975.00058

Medved', D., \& Kavčič, S. (2012). An empirical study of efficiency in Croatia and Slovenia insurance markets. Ekonomska Istraživanja, 25(1), 105-120.

Moshirian, F. (1999). Sources of growth in international insurance services. Journal of Multinational Financial Management, 9(2), 34-49.

Moshirian, F. (1997). Foreign direct investment in insurance services in the United States. Journal Multinational Financial Management, 7(2), 159-173.

OECD (2008). Insurance Statistics Yearbook 1997-2006.

OECD (2011). Insurance Statistics Yearbook 2003-2010.

OECD (2015). Insurance Statistics Yearbook 2007-2014.

OECD (2016). OECD Business and Finance Outlook 2015.

OECD (2017). OECD Business and Finance Outlook 2016.

Outreville, J.F. (1996). Life insurance market in developing countries. Journal of Risk and Insurance, 63(2), 263-278. https://doi.org/ 10.2307/253745

Outreville, J.F. (1990). The economic significant of insurance markets in developing countries. Journal of Risk and Insurance, 18(3), 487-498. 
Owsiak, S. (2002). Metodologiczne aspekty badań nad sektorem finansowym. In S. Owsiak (Ed.), Sektor finansowy w Polsce. Warszawa: PWE.

Pelegrin, F., Schich, S., \& de Serres, A. (2002). Increases in business investment rates in OECD countries in the 1990s: How much can be explained by Fundamentals? (OECD Economic Department Working Papers, No. 327).

Pye, R. (2005) The evolution of financial services in transition economies: An overview of the insurance sector. Post-communist Economies, 17(2), 205-223.

Sankaramuthukumar, S., \& Alamelu, K. (2012). A SWOT analysis of Sri Lankan insurance sector. The Journal of Risk and Insurance, 9(1), 27-47.

Sawadogo, R, \& Guèrineau, S. (2015). Does insurance development affect the financial markets in developing countries?. Etudes et Documents, 20, CERDI. Retrieved from http://cerdi.org/production/show/id/1718/type_production_id/1 on October 15, 2018.

Sen, S. (2007). Are life insurance demand determinants valid for selected Asian economies and India? (Paper for Presentation at Annual Meeting of APRIA, 1-27). Institute for Social and Economic Change. Retrieved from https://www.scribd.com/document/230968492/13507Paper-APRIASubir-Draft on October 15, 2018.

Sen, S., \& Madheswaran S. (2013). Regional determinants of life insurance consumption: evidence from selected Asian economies. Asian-Pacific Economic Literature, 27(2), 86-103. https://doi.org/10.1111/apel.12024

Ward, D., \& Zurbruegg, R. (2000). Does insurance promote economic growth? Evidence from OECD countries. Journal of Risk and Insurance, 67(4), 489-506. https://doi.org/10.2307/253847

Wieczorek-Kosmala, M. (2016). Non-life insurance markets in CEE countries - part I: products' structure. Journal of Economics and Management, 25(3), 109-125.

Zhang, C., \& Zhu, N. (2005). Determinants of the development of insurance in China under the globalization (Working Paper Centre D'Études et de Recherches sur le Développement International). Retrieved from https://pdfs.semanticscholar.org/5b03/2f2e73daba3584185301f73be197250e7fe9.pdf on October 15, 2018.

Zheng, W., Liu, Y., \& Deng, Y. (2009). A comparative study of international insurance sector. The Geneva Papers on Risk and Insurance - Issues and Practice, 34(1), 85-99. https://doi.org/10.1057/gpp.2008.37

Zietz, E. N. (2003). An examination of the demand for life insurance. Risk Management and Insurance Review, 6(2), 159-191. https://doi.org/ 10.1046/J.1098-1616.2003.030.x 


\section{Authors}

The contribution share of authors is equal and amounted to $50 \%$ for each of them.

\section{Sławomir I. Bukowski}

Professor in Economics and Finance, the Faculty of Economics and Finances, Kazimierz Pulaski University of Technology and Humanities in Radom, Poland. His research interests include the integration of financial markets, international finance, and econometrics methods.

Correspondence to: Prof. dr hab. Sławomir Bukowski, Faculty of Economic and Finance, Kazimierz Pulaski University of Technology and Humanities in Radom, ul. Chrobrego 31, 26-600 Radom, Poland, e-mail: s.bukowski@uthrad.pl

ORCID ㄴ http://orcid.org/0000-0001-8039-895X

\section{Marzanna Lament}

Assistant Professor in Finance and Accounting, PhD, the Faculty of Economics and Finances, Kazimierz Pulaski University of Technology and Humanities in Radom, Poland. Her research interests includes the accounting and finance of insurance companies and insurance market.

Correspondence to: Dr Marzanna Lament, Faculty of Economic and Finance, Kazimierz Pulaski University of Technology and Humanities in Radom, ul. Chrobrego 31, 26-600 Radom, Poland, email:m.lament@uthrad.pl

ORCID (1) http://orcid.org/0000-0001-5185-6990

\section{Acknowledgements and Financial Disclosure}

The authors would like to thank anonymous referees for their useful comments, which allowed for increasing the value of this article.

\section{Copyright and License}

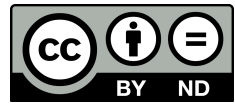

This article is published under the terms of the Creative Commons

Attribution - NoDerivs (CC BY-ND 4.0) License http://creativecommons.org/licenses/by-nd/4.0/

\section{Published by Cracow University of Economics - Krakow, Poland}


